UDC 621.391

\title{
METHOD OF TRANSMITTING INFORMATION ON THE INTERNET OF THINGS
}

\author{
${ }^{1}$ Yaroslav O. Mikhnenko, ${ }^{1}$ Mariia A. Skulysh, ${ }^{1}$ Vasil V. Kurdecha, ${ }^{2}$ Galyna E. Mikhnenko \\ ${ }^{1}$ Institute of Telecommunication Systems \\ Igor Sikorsky Kyiv Polytechnic Institute, Kyiv, Ukraine \\ ${ }^{2}$ Department of English for Engineering \\ Igor Sikorsky Kyiv Polytechnic Institute, Kyiv, Ukraine
}

\begin{abstract}
Background. The IoT technology covers devices and appliances, such as thermostats, home security systems and cameras, lighting fixtures as well as other household appliances that support one or more shared ecosystems, and can be controlled by devices associated with that ecosystem, for example with smartphones and smart speakers. However, there are a lot of problems to be solved. One of these problems is the power supply of wireless sensors on the Internet of Things.

Objective. The purpose of the study is to reduce energy consumption of IoT devices in the process of transmitting the collected data by regulating the number of transmission transactions.

Methods. The analysis of the existing energy saving methods in IoT devices shows that the problem of choosing the optimal buffer size has not yet been solved. An optimization problem has been formulated, which allows considering the requirements for the quality of transmission of both information flows and communication systems that provide this transfer.

Results. The article presents the modified method of information transmission to improve the energy efficiency of the network. The need to allocate a queue buffer at each of the nodes and explain the operation of the node using the queue buffer has been highlighted. The scheme of the project with the use of the modified Sleep / Wake algorithm has been created.

Conclusions. The main idea of the method is to allocate a buffer at each node with a certain threshold value, and if the latter is exceeded, the transmission of information packets will begin. This increases the service life of WSN by $14.8 \ldots 20.6 \%$ compared to the IoT sensor networks that use an asynchronous queue cycle.
\end{abstract}

Keywords: IoT; energy efficiency; life expectancy of the IoT network.

\section{INTRODUCTION}

Constant advances in technology and wireless communications give humanity the opportunity to make small and cheap sensors that switch to each other wirelessly. The sensors used, regardless of the time of their connection to the system, create a network of wireless sensor element (Wireless sensor network (WSN)). The sensors convert the collected physical data into a form that can enable the user to understand them. WSN technology is growing rapidly, becoming cheaper and easier to use, and allows the full usage of various applications in such networks. WSN is most popular when using a large number of applications that manage surveillance (health care environment, seismic activity monitoring, etc.) and management (detection and tracking of objects).

\section{OVERVIEW AND PROBLEM STATEMENT}

Wireless sensor networks consist of a range of sensitive nodes[1],[4] that are located in areas of use (e.g. in deserts, forests, and caves) for information and do not necessarily have a constant power source. In each reading element of the node, the battery energy is limited by a significant increase in energy consumption[2],[3], which becomes a major problem. This raises the issue of increasing the lifetime of the network remote from the source of constant power.

\section{SOLUTION USED}

Theoretically, nodes can save energy between active and sleep mode. The quantitative ratio between these modes is the operating cycle of the wireless network. When using this method, the WSN is adapted, and the nodes of the sensing elements are turned on and off during exposure and when they must be used. Network encryption techniques that protect the use of information and further encode incoming and outgoing packets of information and, thus, transmit the encrypted packet to the main node of network software nodes use 
a single jump for communication, but all other types of nodes use multichannel communication (Fig.1).

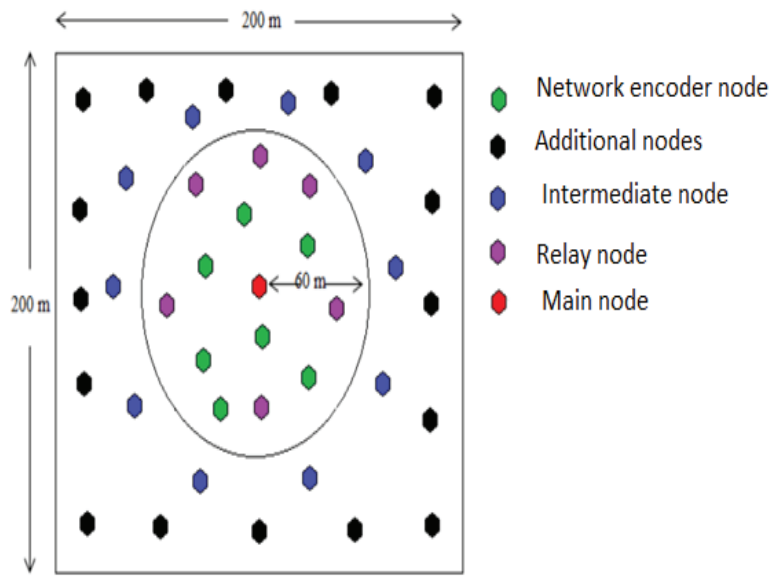

Fig.1 The scheme of the sensor network of the Internet of Things

The WSN duty cycle factor is divided into three main types: random WSN, coordinated WSN, and custom WSN. In nodes of ordinary elements, data packet transfer is switched on or off at random. Random quadratic WSN is square-dimensional and rectilinear because no additional overhead expenses are required. However, the disadvantage of a random WSN cycle is that it does not go to sleep while maintaining the network state. This development will generate significant traffic, i.e. the loop will not be used at a higher level of information usage.

In a coordinated working cycle, the substance of the sensing element interacts with each other through the exchange of information and messages. However, it requires further exchange of information to broadcast the active sleep schedules of each node. This will lead to significant traffic and overhead expenses. Typically, queue detection and a coordinated workflow management mechanism are proposed to provide a queue management to conserve energy and reduce latency. The designed method does not need to obtain specific status information from neighboring nodes, but it uses only the assignment queue lengths that can be obtained at the nodes. Changes in network conditions implicitly occur as a result of queue states that have the risk or capacity of network states. Obtaining the length of the queue and its variations of the node of the sensing element (Fig. 2) helps to provide a mode of distributed network controller for the duty cycle. Thus, queue recognition and coordinated WSN with the basic cycle associated with the execution of mandatory operations are a separate mode.

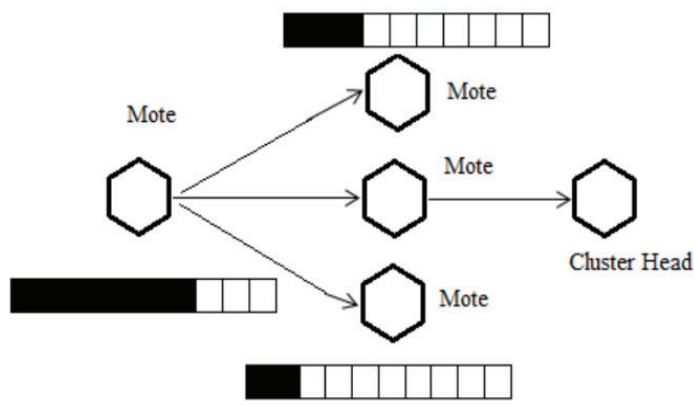

Fig. 2 The length of the queue and the variations of the sensing element node

The system is taken into account when $\mathrm{N}$ devices are uniformly scattered in space A. All $\mathrm{N}$ nodes of the device are an adaptive cycle Duty Enabled, i.e. switching between active and sleep state keeps their queue values within the outer zone B. The nodes are divided into two commands resembling relay devices and the nodes of the devices in linear network programs. The nodes of the active relay devices (R) transmit information that is generated externally in the same way as in the bottleneck area. In the bottleneck area, the relay nodes communicate with the drain using one-step communication, and the relay node transmits information packets to other relay nodes and program nodes that use communication with multiple channels. Active linear networks of software nodes of the device write information of the relay node in the code before transmission to the drain. This node will use one step to contact the drain. The nodes of the sheet device sporadically sense the information and transmit it to neighboring nodes in the direction of runoff. The nodes of the intermediate device sporadically sense the information and transmit the detected information and the received data in the direction of the center of the network S.

The upper limit of network lifetime for queue detection is defined as:

$$
t \leq \frac{d_{m} B E_{b}}{S_{x}}=T_{u} D
$$

where the value of $S_{\mathrm{x}}$ is taken from:

$$
S_{x}=p \alpha_{31} \frac{n}{n-1} r_{s}\left[D(A-B) \frac{m+1}{2}+\iint x d_{s}\right]+B d_{m}\left[p-r_{s}\left(e_{s}-\alpha_{12}\right)+(1-\right.
$$

Each node of the device covers the variety of the received queue and detects the queue attached to it one or more - from alternative nodes. At each node of the device, the packets arrive and depart, except for the terminal nodes and the main node. The planned approach is to allocate a buffer on each node to one queue of inventory. After the buffer occupancy exceeds the threshold, the switch begins to operate on the device node in the energy mode in order to try to transmit all 
the information until the buffer occupancy falls below the limit,. If the buffer size is below the threshold, the device enters the sleep mode.

Thus, we see the dependence between the size of the buffer and the change in the number of packet transmission cycles, and as a consequence - the lifetime of the sensor network. That is, there are two restrictions on the minimum and maximum buffer size.

The first limitation - the size of the buffer tends to the maximum possible. In this case, when the buffer is full and packet transmission begins, the active transmission time per session increases.

The second limitation - the size of the buffer tends to the minimum possible. This option has the inverse form, but the result - the total energy consumption of the network - is similar to the first limitation. For example, if you use a buffer with less capacity than the length of the sending data packet, the node will have long active transmission states and will increase the number of work sessions.

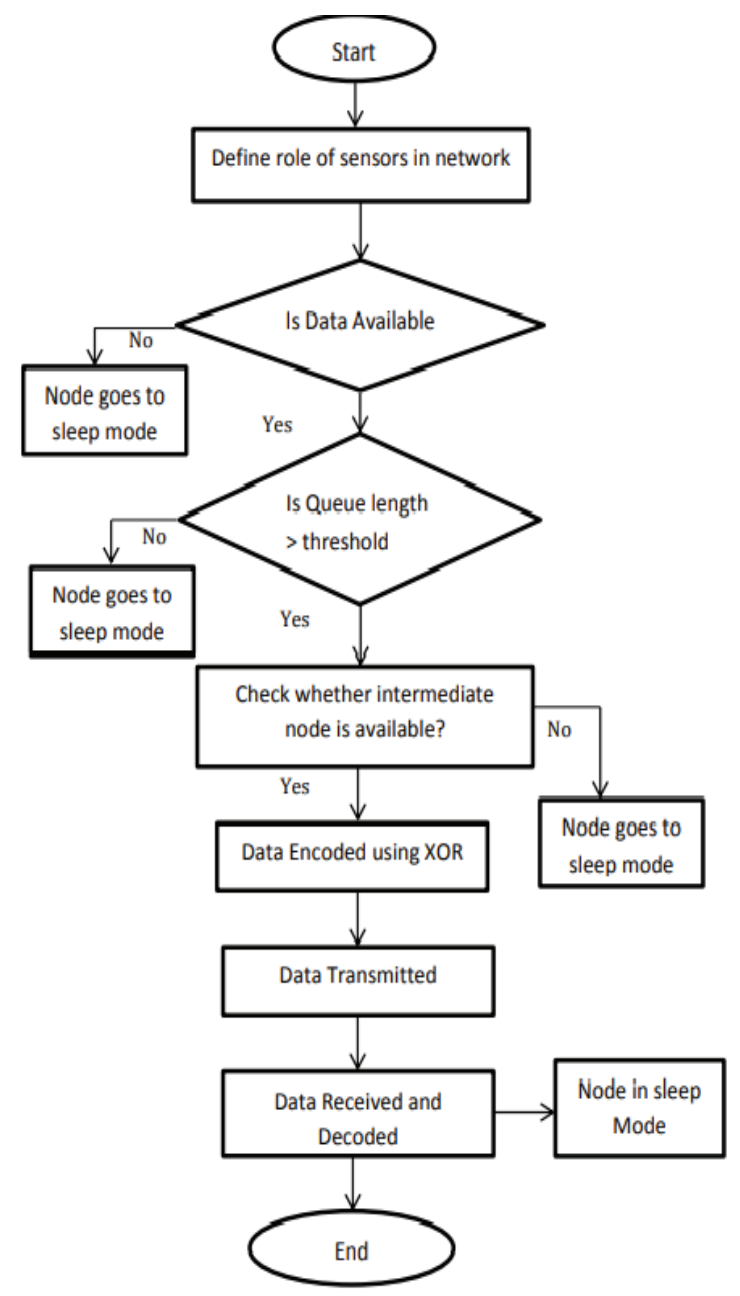

Fig. 3 The general scheme of the project
The place of using the coordinated method of information packet transmission can be seen in Fig. 4. If we pay attention to one of the three levels of the Internet of Things architecture, namely, the level of the so-called Edge, it is clear that at this level are nodes with sensors and actuators. It is in the nodes of the "Smart" IoT Device that the Sleep / Wake algorithm changes to increase energy efficiency and increase system life. Since "Smart" IoT Device [8] best and most cooperate with the human life cycle [7], it was more appropriate for them [9], [10] to use a modified method of information transfer, thereby increasing energy efficiency and lifetime of networks.

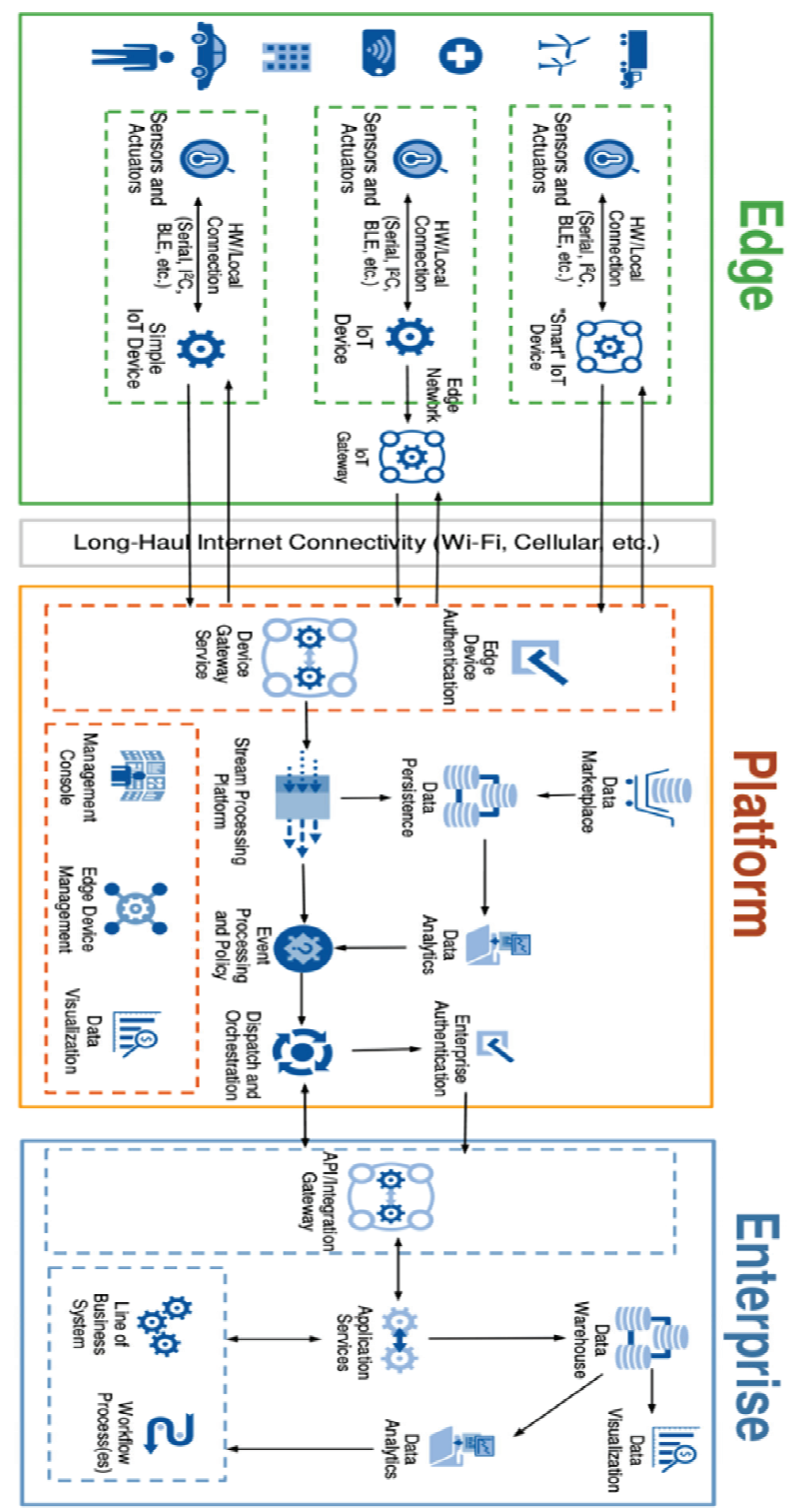

Fig. 4 Architecture of the Internet of Things using a coordinated method 
In this paper, we consider the area of wireless sensor network $200 \times 200 \mathrm{~m}^{2}$, narrow zone diameter $60 \mathrm{~m}$, the number of nodes -1000 , battery energy $25 \mathrm{~kJ}$, sleep energy $30 \mathrm{~J}$, transition length 2 , the number of bits 96 and buffer threshold 12 bits [6].

Fig. 5 shows the power consumption per node in a wireless sensor network with a change in duty cycle. When the value of the duty cycle is 0.01 , the energy consumption is minimal, i.e. $30.1 \mathrm{~J}$, and the duty cycle is 0.1 , the energy consumption is $1000 \mathrm{~J}$. As the duty cycle increases, the energy consumption increases.

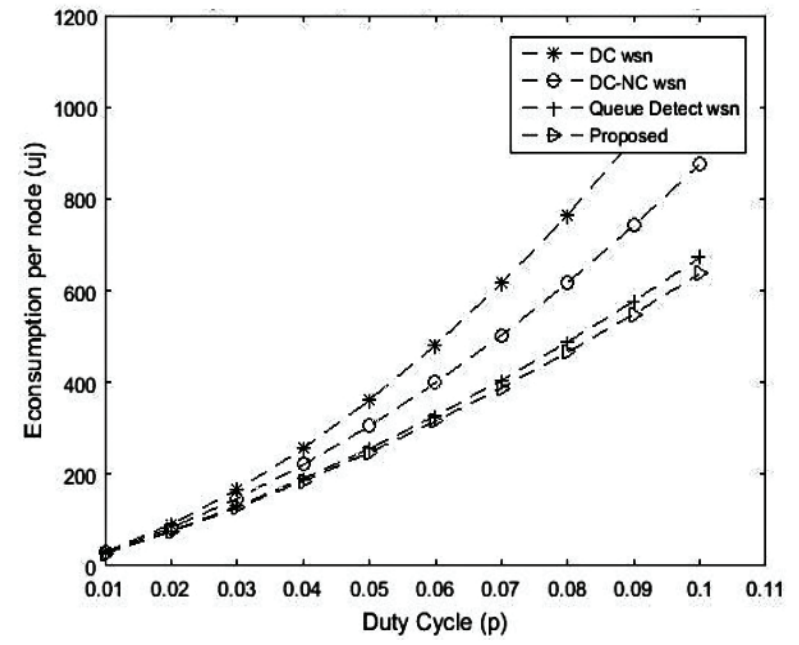

Fig. 5 Energy consumption of the sensor network using a random cycle

The figure shows that the power consumption is maximum for random cycles used in wireless sensor networks and minimal for queueing with a coordinated network with a cyclic cycle. Table 1 compares the energy consumption for different technologies.

Energy consumption for different methods

\begin{tabular}{|c|c|c|}
\hline $\begin{array}{c}\text { Methods in } \\
\text { wireless sensor } \\
\text { networks on the } \\
\text { Internet of Things }\end{array}$ & $\begin{array}{c}\text { Energy use } \\
\text { for } \mathrm{p}=0.01\end{array}$ & $\begin{array}{c}\text { Energy use } \\
\text { for } \mathrm{p}=0.1\end{array}$ \\
\hline $\begin{array}{c}\text { Arbitrary Work } \\
\text { Cycle }\end{array}$ & 30.1 & 1110.4 \\
\hline $\begin{array}{c}\text { Network coded } \\
\text { cycle }\end{array}$ & 28.58 & 876.3 \\
\hline $\begin{array}{c}\text { Queue } \\
\text { detection using } \\
\text { network coding }\end{array}$ & 27.25 & 672.09 \\
\hline $\begin{array}{c}\text { The proposed } \\
\text { method (detection } \\
\text { stage and } \\
\text { coordinated duty } \\
\text { cycle) using buffer }\end{array}$ & 27.03 & 637.11 \\
\hline
\end{tabular}

Fig. 6 shows a comparison of the lifetime for a random loop, a coded network loop, network coding with a queue detection technique, and a queue detection with a coordinated WSN loop.

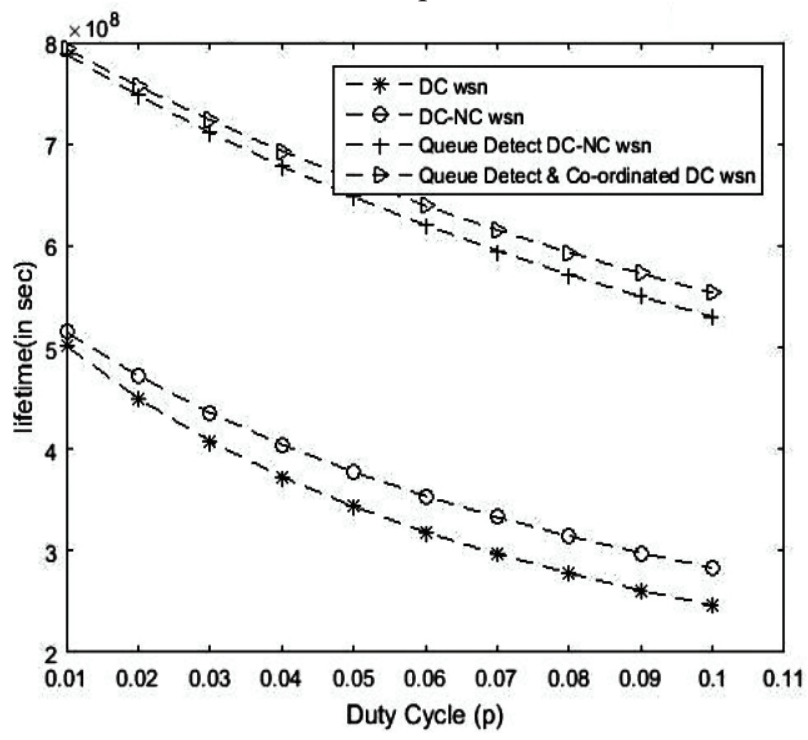

Fig. 6 The service life of the sensor network using a random mode cycle, network coding with a cycle, the method of queuing detection and the proposed system

Table 2

Comparison of life expectancy for different methods

\begin{tabular}{|c|c|c|}
\hline $\begin{array}{c}\text { Methods in } \\
\text { wireless sensor } \\
\text { networks on the } \\
\text { Internet of } \\
\text { Things }\end{array}$ & $\begin{array}{c}\text { Life } \\
\text { expectancy at } \mathrm{p} \\
=0.01\end{array}$ & $\begin{array}{c}\text { Life } \\
\text { expectancy at } \mathrm{p} \\
=0.1\end{array}$ \\
\hline $\begin{array}{c}\text { Arbitrary } \\
\text { Work Cycle }\end{array}$ & $5.02 * 10^{\wedge} 8$ & $2.45^{*} 10^{\wedge} 8$ \\
\hline $\begin{array}{c}\text { Network } \\
\text { coded cycle }\end{array}$ & $5.17^{*} 10^{\wedge} 8$ & $2.81^{*} 10^{\wedge} 8$ \\
\hline $\begin{array}{c}\text { Queue } \\
\text { detection using } \\
\text { network coding }\end{array}$ & $7.89 * 10^{\wedge} 8$ & $5.28^{*} 10^{\wedge} 8$ \\
\hline $\begin{array}{c}\text { The proposed } \\
\text { method } \\
\text { (detection stage } \\
\text { and coordinated } \\
\text { duty cycle) using } \\
\text { buffer }\end{array}$ & $7.94 * 10^{\wedge} 8$ & $5.52^{*} 10^{\wedge} 8$ \\
\hline
\end{tabular}

Comparing the two methods of transmitting data packets in sensor networks, namely the asynchronous and coordinated method with the buffer of the inventory queue (modified method), we have obtained Fig. 7: 


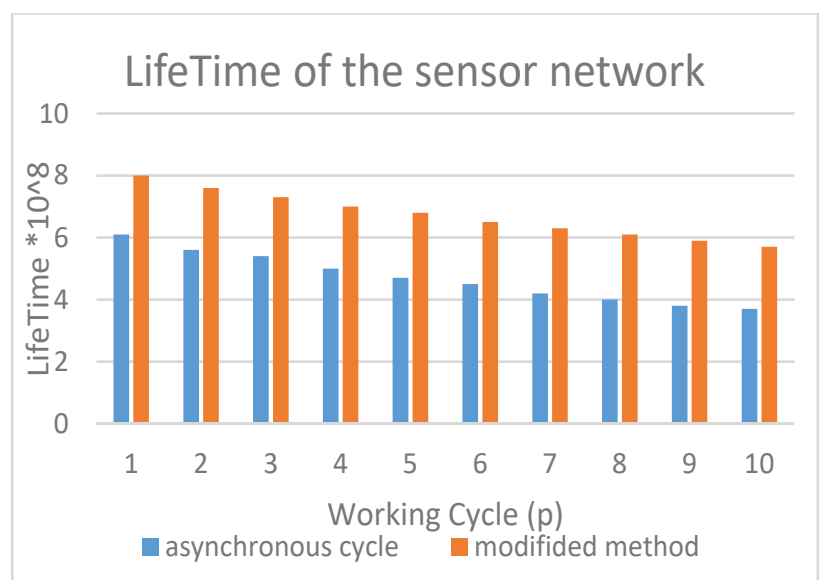

Fig. 7 Lifetime of the sensor network using asynchronous and modified methods of data packet transmission

Thus, Fig. 7 shows the changes in system life time in terms of the number of duty cycles using two methods of transmitting data packets. You can see an increase in the lifetime of the sensor network by $20 \%$ when using a modified method compared to the asynchronous transmission method.

\section{CONCLUSIONS}

The process of choosing a method of transmitting information to the sensor network of the Internet of Things plays an important role in network design, as the method depends not only on the speed of receiving information packets, but also the lifetime of energyindependent sensor network. The main idea of the method is to allocate a buffer at each node with a certain threshold value, and, in case of the excess of the latter, the transmission of information packets will be started. This method increases the lifetime of the WSN by $14.8 \ldots 20.6 \%$ compared to the sensor networks of the Internet of Things which use an asynchronous cycle of queues.

\section{References}

1. Dhar D. Energy Efficient Routing Algorithm with sleep scheduling in Wireless Sensor Network [Electronic resource] / D. Dhar, K. Praveen // International Journal of Computer Science and Information Technologies - Retrieved from https://pdfs.semanticscholar.org/a 7b3/bd02a2ceb6b6f7b 4ba1c897d38055146a137.pdf.

2. Gottheil A. Energy Efficiency with IoT [Electronic resource] / Avrohom Gottheil. - 2017. Retrieved from https://theiotmagazine.com/energyefficiency-with-iot-99afb953579a .

3. How can we improve energy efficiency in IOT? [Electronic resource]. - 2019. - Retrieved from
https://www.quora.com/How-can-we-improve-energyefficiency-in-IOT.

4. Narsingh G. Lifetime Improvement Of Wireless Sensor Network Using Co-Ordinated Duty Cycle And Queue Detect Technique [Electronic resource] / G. Narsingh, K. Rajeev // International Research Journal of Engineering and Technology (IRJET). $2016 . \quad-\quad$ Retrieved from https://pdfs.semanticscholar.org/2c85/f004a4373bf4b41 fe5070eb7ba44f7e4eff2.pdf.

5. Runze W. An energy-efficient sleep scheduling mechanism with similarity measure for wireless sensor networks [Electronic resource] / W. Runze, X. Naixue. - 2018. - Retrieved from https://hcisjournal.springeropen.com/articles/10.1186/s13673-0180141-x.

6. Contron. Internet of things: hyper-association of infrastructure [Electronic resource] / Kontron Retrieved from https:/vkt.ua/articles/internet-veshhejgiperobedinenie-infrastruktury/.

7. Overview of the Most Popular Smart Home Devices. - 2019. - http://iotlineup.com/.

8. Pupena O. Fundamentals of the Internet of Things [Electronic resource] / Oleksandr Pupena. $2019 . \quad$ - Retrieved from http://edu.asu.in.ua/mod/book/tool/print/index.php?id=1 12\# $\#$ ch230.

9. Rouse M. IoT devices (internet of things devices) [Electronic resource] / Margaret Rouse. - 2018. - Retrieved from https://internetofthingsagenda.techtarget.com/definition IoT-device.

10. Development of IOT devices [Electronic resource]. - 2019. - Retrieved from https://evergreens.com.ua/ru/products/development/iotdevices.html.

11. LARYSA, Globa; MARIIA, Skulysh; SVITLANA, Sulima. Method for resource allocation of virtualized network functions in hybrid environment. In: 2016 IEEE International Black Sea Conference on Communications and Networking (BlackSeaCom). IEEE, 2016. p.p. 1-5.

12. GLOBA, L., et al. Quality control for mobile communication management services in hybrid environment. In: The International Conference on Information and Telecommunication Technologies and Radio Electronics. Springer, Cham, 2018. p.p. 76-100.

13. LARISA, Globa; MARIIA, Skulysh; ANNA, Zastavenko. The method of resources allocation for processing requests in online charging system. In: The Experience of Designing and Application of CAD Systems in Microelectronics. IEEE, 2015. p.p. 211-213. 
14. SKULYSH, Mariia; SULIMA, Svitlana. Management of multiple stage queuing systems. In: The Experience of Designing and Application of CAD Systems in Microelectronics. IEEE, 2015. p.p. 431-433.

15. M. Bhardwaj, T. Garnett, and A. Chandrakasan, "Upper bounds on the lifetime of sensor networks," in Proc. 2001 IEEE ICC, pp. 785-790.

16. D. Estrin, R. Govindan, J. Heidemann, S. Kumar, Next century challenges: scalable coordination in sensor networks, in: Proceedings of the 5th Annual ACM/IEEE International Conference on Mobile Computing and Networking, Seattle, Washington, USA, August 1999, pp. 263-270.

17. C. F. Hsin and M. Liu, "Randomly duty-cycled wireless sensor networks: dynamic of coverage," IEEE Trans. Wireless Commun., vol. 5, no. 11, pp. 31823192, 2006.

18. H. Zhang and J. C. Hou, "On the upper bound of $\alpha$-lifetime for large sensor networks," ACM Trans. Sen. Netw., vol. 1, no. 2, pp. 272-300, 2005.

19. S. Slijepcevic. Power efficient organization of wireless sensor networks [Electronic resource] / S. Slijepcevic, M. Potkonjak. - 2002. - Retrieved from https://ieeexplore.ieee.org/abstract/document/936985/au thors\#authors .

20. Bhattacharyya, S. (2017). Handbook of Research on Recent Developments in Intelligent Communication Application. Retrieved from https://books.google.co.in

21. H. Schaffers, N. Komninos, M. Pallot, B. Trousse, M. Nilsson, and A. Oliveira, "Smart Cities and the Future Internet: Towards Cooperation Frameworks for Open Innovation", The Future Internet, Lecture Notes in Computer Science Volume 6656, pp. 431-446, 2011.

22. H. Kagermann, W. Wahlster, and J. Helbig, "Recommendations for implementing the strategic initiative INDUSTRIE 4.0 Final report of the Industrie 4.0 Working Group," 2013.
23. J. Davis, T. Edgar, J. Porter, J. Bernaden, and M. Sarli, "Smart manufacturing, manufacturing intelligence and demand-dynamic performance," Computers \& Chemical Engineering, vol. 47, pp. 145156, 2012.

24. P.C.Evans, M.Annunziata, Industrial Internet: Pushing the Boundaries of Minds and Machines, November 2012, Available online at http://www.ge.com/docs/chapters/

Industrial_Internet.pdf.

25. W. Ye, J. Heidemann, and D. Estrin, "An Energy-Efficient MAC Protocol for Wireless Sensor Networks," Proc. IEEE INFOCOM pp. 1567-1576, 2002.

26. Mrs. Rakhi Khedikar1, Dr. Avichal Kapur2 and Yogesh Survanshi3," Maximizing a Lifetime of Wireless Sensor Network by Scheduling",2011.

27. J. Kim, X. Lin, N. B. Shroff, P. Sinha, "Minimizing delay and maximizing lifetime for wireless sensor networks with anycast", Journal IEEE/ACM Transactions on Networking, vol.19, no.6, pp.851-864, June 2008.

28. W.L. Lee, A. Datta, R. Cardell-Oliver, "FlexiTP: A FlexibleSchedule-Based TDMA Protocol for Fault-Tolerant and Energy Efficient Wireless Sensor Networks," IEEE Transactions on Parallel and Distributed Systems, , vol.19, no.6, pp.851-864, June 2008.

29. A Abbasi, K Akkaya, M. Younis, A distributed connectivity restoration algorithm. wireless sensor and actor networks. In: Proceedings of the 32nd IEEE conference on local computer networks (LCN 2007), Dublin, Ireland, October 2007.

30. Zheng, S. Radhakrishnan, V. Sarangan, PMAC: An adaptive energy efficient MAC protocol for wireless sensor networks, in: Proceedings of the IEEE International Parallel and Distributed Processing Symposium, 2005, pp. 65-72

Міхненко Я.О., Скулиш М.А., Курдеча В.В., Міхненко Г.Е.

Метод передачі інформації в Інтернеті Речей

Проблематика. Технологія ІоТ охоплює пристрої та прилади, такі як термостати, системи домашньої безпеки та камери, освітлювальні прилади та інші побутові прилади, що підтримують одну або кілька спільних екосистем, і ними можна керувати за допомогою пристроїв, пов'язаних із цією екосистемою, наприклад, за допомогою смартфонів та розумних колонок. Однак існує багато проблем, які потрібно вирішити. Однією 3 цих проблем є живлення бездротових датчиків в Інтернеті речей.

Мета дослідження. Зменшити енергозатрати пристроїв ІоТ в процесі передачі зібраної інформації за рахунок регулювання кількості транзакцій передачі.

Методика реалізації. Аналіз існуючих методів енергозбереження у пристроїв ІоТ показав, що задача вибору оптимального розміру буферу досі не вирішена. Була сформульована оптимізаційна задача, яка дозволила врахувати вимоги до якості передачі, як інформаційних потоків, так і систем зв'язку, які забезпечують передачу. 
Результати дослідження. У статті представлена модифікація способу передачі інформації для підвищення енергоефективності мережі. Підкреслюється необхідність виділення буфера черги на кожному з вузлів та пояснення роботи вузла за допомогою буфера черги. Створено схему проєкту із застосуванням модифікованого алгоритму Sleep / Wake.

Висновки. Основна ідея методу полягає у виділенні буфера на кожному вузлі з певним пороговим значенням, і в разі перевищення останнього розпочнеться передача інформаційних пакетів. Це збільшує термін служби WSN на 14,8.. 20,6\% порівняно з сенсорними мережами Інтернету речей, які використовують асинхронний цикл черг.

Ключові слова: ІоТ; енергоефективність; тривалість життя мережі ІоТ.

\section{Михненко Я.О., Скулыш М.А., Курдеча В.В., Михненко Г.Э.}

Метод передачи информации в Интернете Вещей

Проблематика. Технология ІоТ охватывает устройства и приборы, такие как термостаты, системы домашней безопасности и камеры, осветительные приборы и другие бытовые приборы, поддерживающие одну или несколько общих экосистем, и ими можно управлять с помощью устройств, связанных с этой экосистемой, например, помощью смартфонов и разумных колонок. Однако существует много проблем, которые нужно решить. Одной из этих проблем является питания беспроводных датчиков в Интернете вещей.

Цель исследования. Уменьшить энергозатраты устройств ІоТ в процессе передачи собранной информации за счет регулирования количества транзакций передачи.

Методика реализации. Анализ существующих методов энергосбережения у устройств ІоТ показал, что задача выбора оптимального размера буфера до сих пор не решена. Была сформулирована оптимизационная задача, которая позволила учесть требования к качеству передачи, как информационных потоков, так и систем связи, обеспечивающих передачу.

Результаты исследования. В статье представлена модификация способа передачи информации для повышения энергоэффективности сети. Подчеркивается необходимость выделения буфера очереди на каждом из узлов и объяснения работы узла с помощью буфера очереди. Создана схема проекта с применением модифицированного алгоритма Sleep / Wake.

Выводы. Основная идея метода заключается в выделении буфера на каждом узле с определенным пороговым значением, и в случае превышения последнего начнется передача информационных пакетов. Это увеличивает срок службы WSN на 14,8 ... 20,6\% по сравнению с сенсорными сетями Интернета вещей, которые используют асинхронный цикл очередей.

Ключевые слова: ІоТ; энергоэффективность; продолжительность жизни сети IоT. 